\title{
Inhibition of calcification of glutaraldehyde pretreated porcine aortic valve cusps with sodium dodecyl sulfate: Preincubation and controlled release studies
}

\author{
Danielle Hirsch, ${ }^{1}$ Joelle Drader, ${ }^{1}$ Theresa J. Thomas, ${ }^{1}$ Frederick J. Schoen, ${ }^{2}$ \\ Judith T. Levy, ${ }^{3}$ and Robert J. Levy ${ }^{1, *}$ \\ ${ }^{1}$ Department of Pediatrics, Kresge II, R5014, University of Michigan, Ann Arbor, Michigan 48109; ${ }^{2}$ Department of \\ Pathology, Brigham and Women's Hospital and Harvard Medical School, Boston, Massachusetts 02115; ${ }^{3}$ Chemistry \\ Department, Eastern Michigan University, Ypsilanti, Michigan 48197
}

Calcification of bioprosthetic heart valves fabricated from glutaraldehyde pretreated bovine pericardium or porcine aortic valves (PAV) is a frequent cause of the failure of these devices. Of all strategies considered thus far, only detergent preincubations using compounds such as sodium dodecyl sulfate (SDS) inhibited PAV bioprosthetic mineralization in circulatory sheep bioprosthetic valve replacements. The present study sought to characterize the mechanism of action of SDS preincubation. Results of transport and material characterization studies showed that SDS had a relatively high affinity for PAV, with a maximum uptake of $167.1 \pm 6.8 \mu \mathrm{g}$ $\mathrm{SDS} / \mathrm{mg}$ tissue over $24 \mathrm{~h}$ at $37^{\circ} \mathrm{C}$ with a partition coefficient of 19.3. The PAV diffusion of SDS was $1.95 \pm 0.3510^{-6} \mathrm{~cm}^{2} / \mathrm{sec}$. The principal effect of SDS on PAV was phospholipid extraction. The residual organic phosphate in the SDS pretreated tissue was
$2.22 \pm 0.72 \mathrm{nmol} / \mathrm{mg}$ tissue compared to the control untreated group with $18.52 \pm 2.1 \mathrm{nmol} / \mathrm{mg}$ tissue. Incubations of PAV specimens in a $1 \%$ SDS solution for $24 \mathrm{~h}$ significantly inhibited calcification after 21 days in subdermal implants in 3-week-old male rats $\left(\mathrm{PAV} \mathrm{Ca}{ }^{2+}=18.0 \pm 11.8 \mu \mathrm{g} / \mathrm{mg}\right.$ ) compared to control $(177.8 \pm 6.0 \mu \mathrm{g} / \mathrm{mg})$. In contrast, coimplants of $30 \%$ SDS silicone rubber polymers, for regional sustained SDS administration, did not impede PAV calcification in 21 day implants $\mathrm{Ca}^{2+}=166.0 \pm 14.0 \mu \mathrm{g} / \mathrm{mg}$ compared to the nondrug silicone matrix controls, $\left.\mathrm{Ca}^{2+}=173.0 \pm 6.6 \mu \mathrm{g} / \mathrm{mg}\right)$. Thus, we conclude that the mechanisms of SDS inhibition of PAV calcification is due to material effects which occur during preincubation, and is not facilitated by sustained SDS administration. (c) 1993 John Wiley \& Sons, Inc.

\section{INTRODUCTION}

Dystrophic calcification of bioprosthetic replacement heart valves fabricated from glutaraldehyde pretreated porcine aortic valves (PAV) is the most frequent cause of their clinical failure. ${ }^{1-3}$ The calcific deposits, composed of calcium phosphates, are intrinsically localized in the gluatraldehyde pretreated PAV connective tissue cells and collagen. ${ }^{4,5}$ Animal model studies have also shown their initial calcific deposits to be cell-associated, with the later involvement of collagen bundles. The proliferation of the calcific depots alters the PAV implant architecture and leads to prosthesis failure because of stenosis or regurgitation, or both.

*To whom correspondence should be addressed.
Although a number of therapeutic strategies involving agents such as diphosphonates, ${ }^{6-8} \mathrm{FeCl}_{3}$, $\mathrm{AlCl}_{3},{ }^{9,10}$ or detergents ${ }^{11}$ have been effective in subdermal studies, thus far, only detergent pretreatment of PAV using various individual detergents, such as sodium dodecyl sulfate (SDS) $)^{11,12}$ or aminooleic acid, ${ }^{13}$ have been effective for preventing the mineralization of PAV bioprostheses implanted in the circulation in sheep studies. However, the mechanism of action of SDS and other detergents is not well understood.

Sodium dodecyl sulfate is an anionic detergent that can hypothetically modify the bioprosthetic tissue in a variety of ways including, perhaps, extraction of various component lipids or proteins, protein denaturation, or charge modification. In vitro studies of metastable calcium-phosphate solutions have demonstrated SDS prevention of the hydroxyapatite for- 
mation in the presence of acidic phospholipids and calcium-phosphate complexed lipids. ${ }^{14}$

The present study was carried out to investigate the mechanism of SDS-mediated inhibition of PAV calcification. The effects of SDS on PAV tissues were characterized in terms of uptake, diffusion, affinity, and phospholipid and protein extraction. Inhibition of PAV calcification in rat subdermal implants due to SDS pretreatment of PAV was also compared to the regional sustained release of SDS using SDS-silicone rubber coimplants.

\section{MATERIALS AND METHODS}

\section{Materials}

Sodium dodecyl sulfate (purity of approx. 99\%), $N$-2-hydroxyethylpiperazine- $N^{\prime}$-2-ethanesulfonic acid (HEPES), and phosphate standard were purchased from Sigma (St. Louis, MO). Radiolabeled sodium dodecyl $\left[{ }^{35} \mathrm{~S}\right]$-sulfate with a specific activity of $62 \mu \mathrm{Ci} / \mathrm{mg}$ was obtained from Amersham (Arlington Heights, IL). $\left[{ }^{14} \mathrm{C}\right]$-Phosphatidylcholine (L- $\alpha$-[cholinemethyl $\left.-{ }^{14} \mathrm{C}\right]$ ) was supplied by New England Nuclear (specific activity $=153 \mathrm{mCi} / \mathrm{mmol}$ ). The Fisher Scientific Company (Fairlawn, NJ), supplied the following reagent grade chemicals: L-ascorbic acid, methanol, chloroform, toluene, $n$-pentanol. Concentrated sulfuric acid and $30 \%$ hydrogen peroxide were purchased from VWR Scientific. Sodium sulfite was obtained from JT Baker Chemical (Phillipsburg, NJ). The scintillation fluid, Ecolume, was purchased from ICN Biomedicals (Irvine, CA). Ammonium molybdate (VI) was obtained from Aldrich (Milwaukee, WI). Ketamine hydrochloride (Aveco, Fort Dodge, IA) and Rompun $^{\circledR}$ (Haver, Shawnee, KA) were used for anesthesia. Porcine aortic valves, crosslinked with glutaraldehyde and stored in $0.2 \%$ glutaraldehyde at $\mathrm{pH} 7.4$, were donated by Medtronic Inc. (Irvine, CA).

\section{Methods: in vitro studies}

\section{Diffusion studies}

The diffusivity, $\mathrm{D}$, for $\left[{ }^{35} \mathrm{~S}\right]-\mathrm{SDS}$ diffusion across PAV leaflets was measured using two chamber diffusion cells at $37^{\circ} \mathrm{C}$ with constant shaking. Each PAV sample was mounted between the two cells after measuring the thickness at three points with a Mitutoyo (Japan) micrometer. The donor solution was a physiologic buffer (50 mM HEPES adjusted to $\mathrm{pH} 7.4$, $0.1 \mathrm{M} \mathrm{NaCl}$ ) containing $1 \% \mathrm{w} / \mathrm{v}$ SDS and preserved with $0.5 \%$ sodium azide. The receptor chamber contained the buffer without SDS. At each time point, the contents of the receptor cell were removed, $\left[{ }^{35} \mathrm{~S}\right]-$ Activity was quantitated with a liquid scintillation counter (Model LS 3801, Beckman, USA) and the SDS diffused calculated as a function of time. The receptor cell was also periodically replenished with fresh solution.

\section{Maximum uptake of $\left[{ }^{35} \mathrm{~S}\right]-S D S$}

The PAV samples (approx. $1 \times 1 \mathrm{~cm}$ ) were incubated in $1 \%, 0.5 \%$, or $0.1 \% \mathrm{w} / \mathrm{v}\left[{ }^{35} \mathrm{~S}\right]-\mathrm{SDS}$ solutions (see above) at $37^{\circ} \mathrm{C}$, with constant shaking. Periodically, the samples were removed, rinsed twice with $1 \mathrm{~mL}$ of distilled water (with a background of $6.9 \pm 1.06 \mu \mathrm{g}$ SDS/mg dry weight) and lyophilized. Then, the samples were dissolved in tissue solubilizer (Solvable, Dupont, Boston, MA) at $55^{\circ}-60^{\circ} \mathrm{C}$ overnight, and then counted for $\left[{ }^{35} \mathrm{~S}\right]$-activity (see above).

\section{SDS-PAV partition study}

To study the affinity of SDS for native PAV leaflet tissue, the latter was placed in a $1.5 \mathrm{~mL}$ Eppendorf vial and immersed in $500 \mu \mathrm{L}$ buffered solution (see above) of $1 \% \mathrm{w} / \mathrm{v}\left[{ }^{35} \mathrm{~S}\right]-\mathrm{SDS}$ at $37^{\circ} \mathrm{C}$ on a shaker $(100 \mathrm{rpm})$. Control vials were prepared containing the radioactive $\left[{ }^{35} \mathrm{~S}\right]-S D S$ solution but without tissue; after $48 \mathrm{~h}, 100 \mu \mathrm{L}$ samples were withdrawn from each vial and counted for radioactivity. The partition coefficient $\left(K_{p}\right)$ was calculated as the ratio between the concentrations of the drug in the tissue and in the buffer, at equilibrium. ${ }^{15}$ The concentration of SDS in the buffer was calculated from the control vials.

\section{Phospholipid extraction and analysis}

The lyophilized, minced samples $(10 \mathrm{mg})$ were homogenized in $1 \mathrm{~mL}$ of $50 \mathrm{mM}$ HEPES buffered saline ( $\mathrm{pH} 7.4$ ) with a $1 \mathrm{~mL}$ Econo-grind homogenizer (Radnoti Glass Technology, Inc., Aracadia, CA) for approximately $1 \mathrm{~h}$ on ice. Then, $20 \mu \mathrm{L}$ of the $\left[{ }^{14} \mathrm{C}\right]-$ labeled phosphatidylcholine solution was added to the sample homogenate in order to quantitate the percentage recovery of the homogenization and extraction procedures. The extraction followed the method of Bligh and Dyer ${ }^{16}$ with the modifications of Merrit et al. ${ }^{17}$ The phospholipid content of the tissues was determined as inorganic phosphate in digested samples. Aliquots of $500-900 \mu \mathrm{L}$ of the redissolved phospholipid residue (in $1 \mathrm{~mL}$ chloroform) were dried and $300 \mu \mathrm{L}$ of concentrated $\mathrm{H}_{2} \mathrm{SO}_{4}$ were added; then the acidic solutions were heated until a brown color developed and left overnight at $25^{\circ} \mathrm{C}$. We added $50 \mu \mathrm{L}$ of $30 \% \mathrm{H}_{2} \mathrm{O}_{2}$ and the tubes were heated until no more gas evolved. The following solutions were added sequentially with mixing: $4 \mathrm{~mL}$ of $0.825 \%$ $\mathrm{Na}_{2} \mathrm{SO}_{3}, 1 \mathrm{~mL}$ of $2 \%\left(\mathrm{NH}_{4}\right)_{6}(\mathrm{Mo})_{7}\left(\mathrm{O}_{2}\right)_{4} \cdot 4 \mathrm{H}_{2} \mathrm{O}$ and $0.1 \mathrm{~mL}$ of a $10 \% \mathrm{~L}$-ascorbic acid solution. After heating the samples of $90^{\circ} \mathrm{C}$ for $10 \mathrm{~min}$ and cooling, the solutions were extracted with $300 \mu \mathrm{L}$ of $n$-pentanol 
and absorbance of the blue pentanol layer was read at $795 \mathrm{~nm}$.

Amino acid analysis

Aliquots of solutions of acid-hydrolyzed porcine tissues ${ }^{18,19}$ were analyzed quantitatively for aminoacid content on a Beckman Spinco 121M Automated Amino Acid Analyzer (Palo Alto, CA).

Formulation of SDS-silicone rubber matrices and SDS release from polymeric matrices

Lyophilized radioactive SDS $(30 \% \mathrm{w} / \mathrm{v})$ was incorporated into prepolymerized MDX4-4210 Silastic (Dow Corning Corporation, Midland, MI) with mixing by uniform levigation. Then, $10 \%$ weight per matrix of the curing agent MDX4-4210 Silastic was added and the mixture was thoroughly admixed. The polymerization took place at $37^{\circ} \mathrm{C}$ using a $650 \mu \mathrm{m}$ thickness mold. Polymerized silicone rubber $\left[{ }^{35} \mathrm{~S}\right]-$ SDS matrices $(1 \times 1 \mathrm{~cm}, 55-60 \mathrm{mg})$ were incubated in $5 \mathrm{~mL}$ of a physiological buffer (50 mM HEPES, $\mathrm{pH} 7.4,0.1 \mathrm{M} \mathrm{NaCl}$ ) at $37^{\circ} \mathrm{C}$ on a shaker stand at $100 \mathrm{rmp}$. At each time point, matrices were transferred into a fresh buffer solution and the previous releasing solutions were diluted with Ecolume and counted for $\left.{ }^{35} \mathrm{~S}\right]-\mathrm{SDS}$ with a liquid scintillation counter (Model LS 3801, Beckman).

\section{Methods: In vivo studies}

Implant and retrieval methods

Three-week-old (50-60 g) male Sprague-Dawley rats (CD strain; Charles River Laboratories, Burlington, MA) were anesthetized by an intraperitoneal injection of xylazine $(0.008 \mathrm{mg} / \mathrm{g})$ and ketamine hydrochloride $(0.057 \mathrm{mg} / \mathrm{g})$. Two subdermal pouches were dissected on the dorsal side of each rat. Preincubated $1 \times 1 \mathrm{~cm}$ pieces of PAV (in $1 \%$ or $0.005 \%$ SDS), or these same pieces attached with sutures to controlled release polymers of similar size, were rinsed with distilled $\mathrm{H}_{2} \mathrm{O}$ and implanted into the subdermal pouches. These animals were maintained on a diet of Rodent Laboratory Chow (Purina Mills, Inc., St. Louis, MO) for 21 days. At this time the animals were sacrificed by $\mathrm{CO}_{2}$ asphyxiation, and the tissue pieces explanted and rinsed with $0.9 \%$ saline. Tissues were individually rinsed with distilled $\mathrm{H}_{2} \mathrm{O}$, freeze-dried, and minced. An acid hydrolysis procedure was used to prepare each sample for calcium analysis by atomic absorption spectroscopy ${ }^{18,19}$ and for a phosphorus assay. ${ }^{20}$
Microscopic analysis

Representative samples of expanded tissue were placed in Karnovsky's fixative (cacodylate buffered $2.5 \%$ glutaraldehyde, $2 \%$ paraformaldehyde at $\mathrm{pH}$ 7.4). Femurs of these same animals were excised at the time of sacrifice and placed in $10 \%$ neutral buffered formalin. Specimens of both tissue and bone were embedded in JB-4 glycomethacrylate medium (Polysciences, Warrington, PA) and sectioned to $2 \mu \mathrm{m}$. these sections were stained with hematoxylin and eosin for general morphology and von Kossa stain for calcium phosphates.

\section{RESULTS}

\section{In vitro transport studies}

\section{Diffusion studies}

The value of $\mathrm{D}$ was calculated from equation 1 :

$$
\mathrm{D}=l^{2} / 6 \cdot \mathrm{t}_{\mathrm{lag}}
$$

where $t_{\text {lag }}$ is the lag time (sec), $l$ is the tissue thickness $(\mathrm{cm}) .^{21}$ The lag time for SDS diffusion through PAV leaflet was experimentally calculated by back extrapolation to the $x$-axis of the steady-state portion of the graph (Fig. 1). The lag times for SDS diffusion through porcine specimens were calculated from Figure 1 and then incorporated in Equation 1. The value of $D$ for SDS was determinated to be $1.95 \pm 0.35 \cdot 10^{-6} \mathrm{~cm}^{2} / \mathrm{sec}$ for PAV, based on two replicate studies.

SDS PAV affinity and partition

The maximum uptake of SDS by PAV leaflet was $167.1 \pm 6.8 \mu \mathrm{g} / \mathrm{mg}$ dried material under the assay

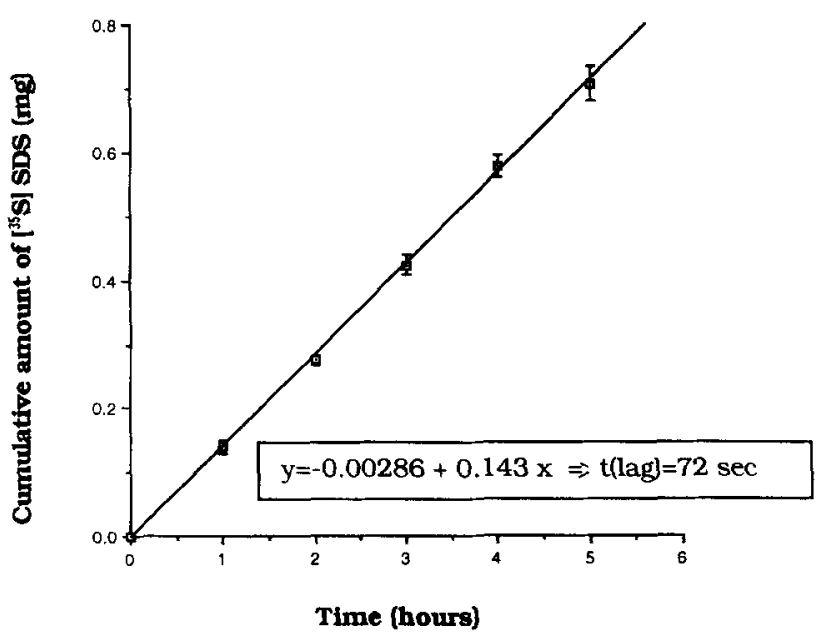

Figure 1. Diffusion of SDS through PAV leaflet membranes tissues. 
system used in these studies with $1 \%$ SDS solution. The maximum uptake of SDS by PAV leaflet in a $0.5 \%$ SDS solution $(166.3 \pm 3.6)$ was similar to the SDS level measured in a $1 \%$ SDS solution. In a $0.1 \%$ SDS solution the maximum uptake of SDS measured dropped to $119.4 \pm 1.2 \mu \mathrm{g} / \mathrm{mg}$ dry PAV. Furthermore, the partition constant $\mathrm{K}_{\mathrm{p}}=\left[\mathrm{C}_{\text {leaflet }}\right] /\left[\mathrm{C}_{\text {solution }}\right]$ of SDS between the PAV leaflet and buffer solution was 19.3

Protein and organic phosphate contents in SDS treated and nontreated PAV leaflets before implant

The results of protein and organic phosphate determinations in unimplanted SDS-treated and nontreated PAV leaflets are presented in Table I. Based on complete amino acid analyses, the average value for the protein level in the unimplanted SDS-treated valves $(67.9 \pm 4.4 \mathrm{mg}$ protein $/ 100 \mathrm{mg}$ dried material) was not significantly different from the protein level in the unimplanted control valves $(79.6 \pm 11.8 \mathrm{mg}$ protein/100 mg dried material). However, the organic phosphate level in SDS-treated valves (2.2 \pm $0.7 \mathrm{nmol} / 100 \mathrm{mg}$ dried material) was significantly lower as compared to the unimplanted nontreated control valves $(18.5 \pm 2.1)$.

\section{Polymer formulation and characterization}

The release profile of $\left.{ }^{35} S\right]$-SDS $(30 \% \mathrm{w} / \mathrm{w})$ from silicone-rubber matrices is shown in Figure 2. Initial release rate results revealed $6.7 \%$ of the SDS eluting after $24 \mathrm{~h}$, but only an additional $20.7 \%$ was released after 1 week. After the initial burst of SDS release, the release rate declined exponentially, reaching a relative plateau by 15 days. The cumulative amount of SDS released at 21 days was $45.15 \pm 2.82 \mathrm{mg}$ SDS/slab (or $2.15 \mathrm{mg} /$ day/coimplanted PAV), corresponding to $45.1 \%$ of the incorporated SDS.

\section{In vivo studies}

Table II shows that preincubations in 1\% SDS of PAV tissue significantly $(P<.05)$ inhibited calcification of rat subdermal implants, as demonstrated by calcium and phosphorus analysis (Table II). PAV preincubation in $0.005 \%$ SDS was not effective for completely inhibiting the calcification, although the calcium level was significantly lower than the control. The porcine tissue coimplanted with $30 \%$ SDSsilicone rubber matrices for 21 days accumulated a similar level of calcium $\left(166.0 \pm 6.6 \mu \mathrm{g} \mathrm{Ca}^{2+} / \mathrm{mg}\right.$ dry weight) as compared to the respective control group (173.0 $\pm 6.6 \mu \mathrm{g} \mathrm{Ca}^{2+} / \mathrm{mg}$ dry weight) (Table II).

Histological studies of explanted specimens confirmed the chemical results (Fig. 3). Calcification of the SDS-treated specimens was markedly reduced relative to control (nontreated) tissue, but had a similar pattern to that typically noted in calcified bioprosthetic tissue, suggesting cell and collagen involvement. ${ }^{18,19}$ Interestingly, there was a suggestion of a zone of relatively diminished calcification in proximity to the SDS-containing polymer suggesting a very localized inhibiting effect, despite the overall severe calcification noted in the SDS-polymer sample. Femurs from animals with either treated tissue or drug release implants showed no alterations relative to femurs from animals not receiving drug.

\section{DISCUSSION}

This study showed that the SDS pretreatment of PAV significantly inhibited calcification of rat subdermal implants. Conversely, the SDS-silicone rubber polymer matrices coimplanted with the bioprosthetic tissue were not effective for preventing PAV mineralization. Thus, these results suggest that an extraction or material modification during SDS preincubation is responsible for preventing PAV calcification, rather than the continuous presence of SDS at what should have been at least comparable levels to the SDS content in preincubated PAV based on the partition constant results (see above).

The principal effect of SDS on PAV was phospholipid extraction (Table I) from membrane sites where they are prevalent. Acidic phospholipids are recognized to be involved in the initiation of both calcification in bone and dystrophic calcification, $18,19,22-24$ possibly, according to Boskey, ${ }^{24}$ as calcium-acidic phospholipid-phosphate complexes. These complexes have also been shown to be membrane constituents. ${ }^{25,26}$ In vitro these same complexes induce

TABLE I

Comparison of Protein and Organic Phosphate Contents in Unimplanted SDS-treated (1\%) and Nontreated PAV Leaflets

\begin{tabular}{lcc}
\hline & $\begin{array}{c}\text { Organic Phosphate } \\
\text { (nmol/mg dry material) }\end{array}$ & $\begin{array}{c}\text { Total Protein } \\
\text { (mg protein/100 mg dry material) }\end{array}$ \\
\hline Nontreated leaflet & $18.5 \pm 2.1(5)$ & $79.6 \pm 11.8(3)$ \\
SDS-treated leaflet & $2.2 \pm 0.7(7)$ & $67.9 \pm 4.4(3)$ \\
\hline
\end{tabular}

*Normalized by using C-phosphatidylcholine internal standard to $100 \%$ recovery for homogenization and extractions procedures; hydrolyzed by the procedure described in Methods. 


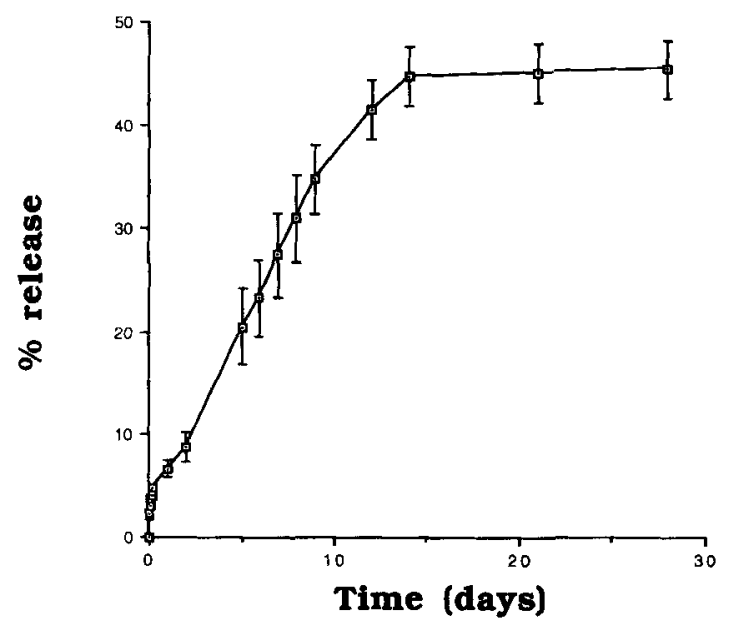

Figure 2. SDS release from silicone-rubber matrices at $37^{\circ} \mathrm{C}$. Each point was the average of five measurements.

hydroxyapatite precipitation from metastable calcium phosphate solutions. ${ }^{27}$ Another related in vitro study showed that SDS had a higher affinity for liposomes than proteins. ${ }^{28}$ In addition, our data demonstrated that the protein level of the bioprosthetic tissue before and after SDS treatment was similar; again, this result indicated the affinity of SDS for lipid extraction rather than proteins of porcine tissues.

Therefore, we propose that SDS preincubation disrupts membranes, thereby releasing phospholipids that are involved in the calcification development. In this hypothesis, SDS solubilizes some membrane phospholipid components of connective tissue cells that have been shown to be the site for early mineralization in bioprosthetic tissue. ${ }^{9,18,19,29}$ Interestingly, a recent study investigated the light and electron microscopic morphology of clinical porcine aortic valve bioprostheses which were subjected to an antimineralization pretreatment consisting of $1 \%$ SDS exposed for $24 \mathrm{~h} .{ }^{30}$ This study did not demonstrate any detectable alterations in morphology or ultrastructure due to SDS, comparing SDS pretreated bioprostheses to controls. ${ }^{30}$
The SDS-membrane related nechanisms for inhibiting bioprosthetic calcification may also be related to the role of alkaline phosphatase in bioprosthetic mineralization, since SDS has been demonstrated to extract alkaline phosphatase from matrix vesicles, thereby completely inhibiting matrix vesicle mineralization studies of in vitro bone mineralization. ${ }^{31,32}$ Prior investigations by our group have demonstrated that alkaline phosphatase is present in both porcine aortic valve leaflet and bovine pericardial bioprosthetic tissue, even after gluataraldehyde fixation. ${ }^{33}$ Furthermore, studies of subcutaneous implants of glutaraldehyde pretreated bovine pericardium have shown that alkaline phosphatase activity increases to maximal levels by $72 \mathrm{~h}$ postimplantation, coincident with the onset of bioprosthetic mineralization, and declines gradually by $21 \mathrm{~h}$ during continuing bulk mineral accumulation. ${ }^{29}$ Alkaline phosphatase investigations were beyond the scope of the present studies concerning SDS pretreatment of porcine aortic valve calcification. However, preliminary results from our laboratory using rat subcutaneous explants of SDS pretreated and control bovine pericardial bioprosthetic tissue demonstrated no significant differences between SDS-treated and control tissues in terms of explant extractable alkaline phosphatase activity despite the SDS inhibition of calcification (Table III).

Previously published results from our group have also shown no relationship between bioprosthetic alkaline phosphatase activity and the efficacy of a number of different types of inhibitors, including biophosphates and metallo-inhibitors. ${ }^{34}$ Furthermore, local controlled release implants containing the alkaline phosphatase inhibitor levamisole did not decrease the level of calcification observed in bovine pericardial rat subdermal implants. ${ }^{35}$ Thus, the relationship between alkaline phosphatase activity and the mechanism of action of SDS for inhibiting bioprosthetic calcification is unclear, and should be the subject of further investigations.

Sodium dodecyl sulfate may also have some role inhibiting the later events in PAV calcification, in which the collagen mineralization takes place. SDS

TABLE II

Calcium and Phosphate Data from PAV (SDS Pretreated and Coimplanted With Polymeric Matrices) Explanted After 21 days

\begin{tabular}{|c|c|c|c|c|}
\hline Treatment & $\mathrm{n}$ & $\mathrm{Ca}(\mu \mathrm{g} / \mathrm{mg}$ dry material $)$ & $\mathrm{P}(\mu \mathrm{g} / \mathrm{mg}$ dry material $)$ & $\mathrm{Ca} / \mathrm{P}$ (molar ratio) \\
\hline \multicolumn{5}{|l|}{ Preincubations } \\
\hline Control & 36 & $177.8 \pm 6.0$ & $115.3 \pm 5.4$ & 1.19 \\
\hline $\operatorname{SDS} 1 \%$ & 21 & $18.03 \pm 11.82^{*}$ & $13.02 \pm 6.92^{*}$ & 1.07 \\
\hline SDS $0.005 \%$ & 10 & $102.3 \pm 12.52^{*}$ & $123.2 \pm 3.2$ & 0.64 \\
\hline \multicolumn{5}{|c|}{ Controlled release studies } \\
\hline Control & 40 & $173.0 \pm 6.6$ & $130.6 \pm 5.26$ & 1.02 \\
\hline $30 \%$ SDS & 22 & $166.0 \pm 13.97$ & $102.4 \pm 5.51^{*}$ & 1.25 \\
\hline
\end{tabular}

${ }^{*} \boldsymbol{P} \leq .05$ compared to respective control groups. 

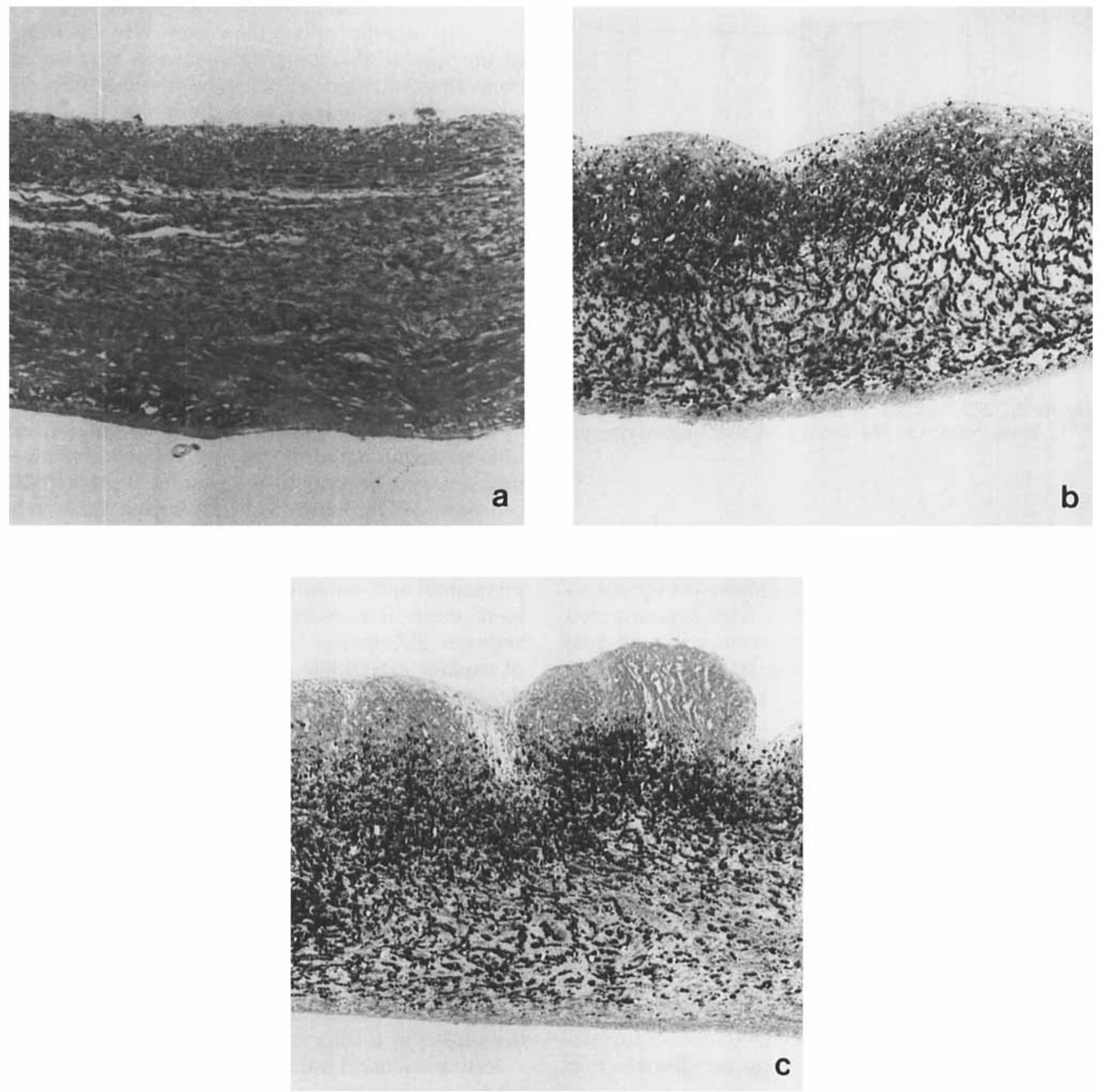

Figure 3. Morphology of explanted tissue, demonstrating inhibition of calcification by SDS pre-incubation but not by drug release in 21 day implants. a) SDS pre-incubated tissue, with minimal calcification. b) Tissue without incubation in SDS. c) Tissue adjacent to polymer containing SDS, with dense calcific deposits demonstrating somewhat reduced intrinsic calcification in proximity to the polymer. Von Kossa stain (calcium phosphates black); original magnification $150 \times$.

has been demonstrated to alter collagen structure so that the resistance of collagen to proteolytic enzymes is annulled ${ }^{36}$ Perhaps SDS pretreatment similarly renders the bioprosthetic collagen secondary and tertiary structures less suitable as a template for calcium phosphate crystallization, and thus further inhibits bioprosthetic calcification.

\section{CONCLUSION}

Evidence in these studies indicates that SDS inhibition of PAV calcification is most likely due to modifications of PAV constituents essential to calcification rather than the binding of this compound to these constituents with a dose-response association. 
TABLE III

Effects of $1 \%$ SDS Preincubation on Calcification and Alkaline Phosphatase Levels in Glutaraldehyde Pretreated Bovine Pericardial Rat Subdermal Explants (72 h and 32 days)

\begin{tabular}{lrr}
\hline Type of Specimen & Calcium $(\mu \mathrm{g} / \mathrm{mg})$ & Alkaline Phosphatase* $^{*}$ \\
\hline SDS, $72 \mathrm{~h}$ & $4.18 \pm 1.27(10)$ & $774.46 \pm 185.49(15)$ \\
SDS, 21 day & $29.16 \pm 5.73(13)$ & $133.13 \pm 38.87(12)$ \\
Control, 72 h & $4.76 \pm 0.49(11)$ & $411.2 \pm 75.81(20)$ \\
Control, 21 day & $102.9 \pm 8.52(10)$ & $72.87 \pm 12.53(10)$ \\
\hline
\end{tabular}

${ }^{*}$ Expressed as nanomoles of paranitrophenolphosphate/minute/mg protein hydrolyzed under established alkaline conditions. ${ }^{34}$ Numbers in parentheses are total samples analyzed.

Phospholipid extraction was most strongly associated with SDS preincubation, and thus further studies on optimal lipid extractions may not only shed light on the crucial events in PAV calcification and its inhibition, but also optimize preventive therapies.

This work, was supported by National Institutes of Health Grant HL 38118. The authors thank Mrs. Catherine Wongstrom for her assistance in preparing the manuscript and Sara Murray, Elena Raskin, and Helen Shing for technical assistance.

\section{References}

1. A. Milano, U. Bortolotti, E. Talenti, et al., "Calcific degeneration as the main cause of porcine bioprosthetic valve failure," Am. J. Cardiol., 53, 1066 (1984).

2. F. J. Schoen and C. E. Hobson, "Anatomic analysis of removed prosthetic heart valves: causes of failure of 33 mechanical valves and 58 bioprostheses, 1980 to 1983," Hum. Pathol., 16, 549 (1985).

3. F.J. Schoen, R.L. Levy, and H.R. Piehler, "Pathological considerations in replacement cardiac valves," Cardiovasc. Pathol., 1, 29 (1992).

4. V.J. Ferrans, S.W. Boyce, M.E. Billingham, et al., "Calcific deposits in porcine bioprostheses: structure and pathogenesis," Am. J. Cardiol., 46, 721 (1980).

5. M. Valente, U. Bortolotti, and G. Thiene, "Ultrastructure substrates of dystrophic calcification in porcine bioprosthetic valve failure," Am. J. Pathol., 119,12 (1985).

6. T.P. Johnston, F. J. Schoen, and R.J. Levy, "Prevention of calcification of bioprosthetic heart valve leaflets by $\mathrm{Ca}^{2+}$ diphosphonate pretreatment," J. Pharm. Sci., 77, 740 (1988).

7. R.J. Levy, M. A. Hawley, F. J. Schoen, et al., "Inhibition by diphosphonate compounds of calcification of porcine bioprosthetic heart valve cusps implanted subcutaneously in rats," Circulation, 71, 349 (1985)

8. G. Golomb, R. Langer, and F. J. Schoen, et al., "Controlled release of disphosphonate to inhibit bioprosthetic heart valve calcification: dose-response and mechanistic studies," J. Controlled Release, 4, 181 (1986).

9. C. L. Webb, F.J. Schoen, W.E. Flowers, et al., "Inhibition of mineralization of glutaraldehydepretreated bovine pericardium by $\mathrm{AlCl}_{3}$. Mechanisms and comparisons with $\mathrm{FeCl}_{3}, \mathrm{LaCl}_{3}$ and
$\mathrm{Ga}\left(\mathrm{NO}_{3}\right)_{3}$ in rat subdermal model studies," Am. J. Pathol., 138, 971 (1991).

10. Y.V. Pathak, J. Boyd, R. J. Levy, and F. J. Schoen, "Prevention of calcification of glutaraldehyde pretreated bovine pericardium through controlled release polymeric implants: studies of $\mathrm{Fe}^{3+}, \mathrm{Al}^{3+}$, protamine sulphate and levamisole," Biomaterials, 11, 718 (1990).

11. M. Jones, E. E. Eidbo, S. L. Hilbert, et al., "The effects of anticalcification treatments on bioprosthetic heart valves implanted in sheep," ASAIO Transactions, 34, 1027 (1988)

12. E. Arbustini, M. Jones, R.D. Moses, et al., "Modifications by the Hancock T6 process of calcification of bioprosthetic cardiac valves implanted in sheep," Am. J. Cardiol., 53, 1388 (1984).

13. J.P. Gott, Pan-Chih, L.M. A. Dorsay, et al., "Calcification of porcine valves: a successful new method of antimineralization," Ann. Thorac. Surg., 53, 207 (1992).

14. A. L. Boskey, M. R. Goldberg, and A.S. Posner, "Effect of diphosphonates on hydroxyapatite formation induced by calcium-phospholipid-phosphate complexes," Calcif. Tiss. Intl., 27, 83 (1979).

15. T.J. Roseman, "Release of steroids from a silicone polymer," J. Pharm. Sci., 61, 46 (1972).

16. E. G. Bligh and W.J. Dyer, "A rapid method of total lipid extraction and purification," Can. J. Biochem. Physiol, 37, 911 (1959).

17. M.V. Merrit, N. J. Licht, C. A. Hatfield, and P.E. Fast, "Membrane fluidity and cholesterol in thymus and spleen cells from mice treated with immunomodulatory drugs," Immunopharmacology, 5, 49 (1982).

18. F.J. Schoen, J.W. Tsao, and R. J. Levy, "Calcification of bovine pericardium used in cardiac valve bioprostheses. Implications for the mechanisms of bioprosthetic tissue mineralization," Am. J. Pathol., 123, 143 (1986)

19. F. J. Schoen, R. J. Levy, and A.C. Nelson, et al., "Onset and progression of experimental bioprosthetic heart valve calcification," Lab. Invest., 52, 523 (1985).

20. P.S. Chen, T. Y. Toribara, and H. Warner, "Microdetermination of phosphorus." Anal. Chem., 28, 1756 (1956).

21. R. Baker, "Diffusion-controlled systems," in Controlled Release of Biologically Active Agents, R. Baker (ed.), New York, Wiley, 1987, p. 39.

22. K. M. Kim, "Lipid matrix of dystrophic calcification and urinary stone," Scanning Electron Microscope, p. 1275 (1983).

23. A. L. Boskey and A.S. Posner," Extraction of calcium-phospholipid-phosphate complex from bone," Calcif. Tiss. Res., 19, 273 (1976). 
24. A.L. Boskey," The role of calcium-phospholipidphosphate complexes in tissue mineralization," Metab. Bone Dis. Rel., 1, 137 (1978).

25. B. D. Boyan-Salyers and A. L. Boskey, "Relationship between proteolipid and calcium-phospholipidphosphate complexes in bacterionema matruchotti calcification,"Calcif. Tiss. Int., 30, 167 (1980).

26. R.E. Wuthier and S.T. Gore, "Partition of inorganic ions and phospholipids in isolated cell, membrane and matrix vesicles fractions: evidence for Ca- $\mathrm{P}_{\mathrm{i}}$-acidic phospholipid complexes," Calcif. Tiss. Res., 24, 163 (1977).

27. A.L. Boskey and A.S. Posner, "The role of synthetic and bone extracted calcium-phospholipidphosphate complexes in hydroxyapatite formation," Calcif. Tiss. Res., 23, 251 (1977).

28. R. Becker, A. Helenius, and K. Simons, "Solubilization of the Semliki Forest virus membrane with sodium dodecyl sulfate," Biochemistry, 14, 1835 (1975).

29. R.J. Levy, F.J. Schoen, W.B. Flowers, and S.T. Staelin, "Initiation of mineralization in bioprosthetic heart valves: studies of alkaline phosphatase activity and its inhibition by $\mathrm{AlCl}_{3}$ or $\mathrm{FeCl}_{3}$ preincubations," J. Biomed. Mater. Res., 25, 905 (1991).

30. M. A. Flomenbaum and F. J. Schoen, "Effects of fixation back pressure and antimineralization treatment on the morphology of porcine aortic bioprosthetic valves," J. Thorac. Cardiovasc. Surg. 105, 154 (1993).
31. S. W. Sajdera, S. Franklin, and R. Fortuna, "Matrix vesciles of bovine fetal cartilage: metabolic potential and solubilization with detergents," Fed. Proc., 35, 154 (1976).

32. H.C. Anderson and S.W. Sajdera," Calcification of rachitic cartilage to study matrix vescile function," Fed. Proc., 35, 148 (1976).

33. A.R. Maranto and F.J. Schoen, "Alkaline phosphatase activity of glutaraldehyde-treated bovine pericardium used in bioprosthetic cardiac valves," Circ. Res., 63, 844 (1988).

34. D. Hirsch, F. J. Schoen, and R. J. Levy, "Effects of metallic ions and diphosphonates in inhibition of pericardial bioprosthetic tissue calcification and associated alkaline phosphatase activity," Biomaterials 14, 371-377 (1993).

35. Y.V. Pathak, J. Boyd, R. J. Levy, and F. J. Schoen, "Prevention of calcification of glutaraldehyde pretreated bovine pericardium through controlled release polymeric implants: studies of $\mathrm{Fe}^{3+}, \mathrm{Al}^{3+}$ protamine sulphate and levamisole," Biomaterials, 11, 718 (1990).

36. H.S. Bleeg, "Non-specific cleavage of collagen by proteinases in the presence of sodium dodecyl sulfate," Scand. J. Dent. Res., 98, 235 (1990).

Received January 15, 1993

Accepted June 8, 1993 